\title{
Pengaruh Pemilikan Aset Teknologi Informasi dan Telekomunikasi terhadap Kemiskinan Rumah Tangga Tani
}

\author{
Pantjar Simatupang ${ }^{\mathrm{a}, \mathrm{*}}$, \& Herlina Tarigan ${ }^{\mathrm{a}}$ \\ ${ }^{a}$ Pusat Sosial Ekonomi dan Kebijakan Pertanian
}

\begin{abstract}
Reducing agricultural household poverty is the key for achieving one digit of national poverty incidence. The research intends to analyze the influence of information and communication technology (ICT) equipment ownership on poverty incidence of the agricultural households in rural Indonesia. The odds of being poor was analyzed using the logit probability model and the media of impact transmission was traced with the expenditure function using the 2017 National Socio Economic Survey (Susenas) data. The results show that the livelihood asset that significantly influence the odds of living out of poverty is access to Information and Communication Technology.
\end{abstract}

Keywords: poverty; agricultural household; sustainable livelihood approach; ICT; logit

\begin{abstract}
Abstrak
Pengurangan prevalensi kemiskinan pada rumah tangga pertanian adalah kunci untuk mewujudkan angka kemiskinan nasional menjadi satu digit. Penelitian ini bertujuan untuk menentukan pengaruh pemilikan aset teknologi informasi dan telekomunikasi (TIK) terhadap kemiskinan rumah tangga tani di pedesaan Indonesia. Kemungkinan terjerumus ke dalam kemiskinan dianalisis dengan menggunakan model probabilitas logit, dan media transmisi dampak diuji dengan fungsi pengeluaran menggunakan data BPS-Susenas 2017. Penelitian menunjukkan bahwa aset penghidupan yang berpengaruh nyata terhadap kemungkinan rumah tangga tani keluar dari kemungkinan masuk ke dalam kemiskinan ialah akses terhadap teknologi informasi dan telekomunikasi digital.
\end{abstract}

Kata Kunci: kemiskinan; rumah tangga pertanian; pendekatan penghidupan berkelanjutan; TIK; logit

Kode Klasifikasi JEL: D83, I32, Q12

*Alamat Korespondensi Penulis: Kawasan Penelitian Pertanian Cimanggu, Jl. Tentara Pelajar No. 3B Bogor 16111. Telp. 0251-8333964, Faks. 0251-8314496. E-mail: pantjar@gmail.com. 


\section{Pendahuluan}

Kemiskinan pedesaan adalah masalah utama penanggulangan kemiskinan di Indonesia, mengingat jumlah penduduk miskin di desa saat ini masih sekitar dua kali lipat dari jumlah penduduk miskin di kota. Oleh karena basis ekonomi pedesaan adalah pertanian, maka bisa dipastikan bahwa sebagian besar dari penduduk miskin di pedesaan menggantungkan hidup pada pertanian. Pengurangan prevalensi kemiskinan pada rumah tangga pertanian adalah kunci untuk mewujudkan penurunan angka kemiskinan nasional menjadi satu digit. Penelitian membuktikan bahwa kinerja pertanian adalah kunci penanggulangan kemiskinan (Simatupang \& Dermorejo, 2003; Suryahadi et al., 2012, McArthur, 2015; Kadir \& Rizki, 2016; Susilastuti, 2018).

Salah satu isu sentral dalam perumusan kebijakan penanggulangan kemiskinan ialah mengidentifikasi determinan kemiskinan rumah tangga pertanian. Penelitian ini mencoba mengkaji peranan pemilikan aset penghidupan terhadap peluang rumah tangga tani di pedesaan Indonesia (RTPD) terbebas dari kemiskinan berdasarkan pendekatan penghidupan berkelanjutan (Sustainable Livelihood Approach/SLA) dengan model analisis probabilitas logit menggunakan data BPS-Susenas 2017.

Penghidupan (livelihood) adalah segala cara yang dilakukan untuk memperoleh kebutuhan dasar agar dapat hidup sehat dan produktif. Dalam sistem perekonomian pasar, livelihood adalah segala kemampuan, aset dan atau pekerjaan yang menjadi sumber pendapatan. SLA berpandangan bahwa livelihood ditentukan oleh ketersediaan, penguasaan (kepemilikan atau akses), pemanfaatan, dan imbal hasil dari aset penghidupan (livelihood asset). Aset livelihood adalah aset yang menjadi basis upaya memperoleh pendapatan untuk memenuhi kebutuhan dasar rumah tangga, baik melalui peranannya sebagai modal berusaha atau bekerja sendiri maupun melalui perolehan imbal hasil dari penggunaan aset oleh orang lain. Aset livelihood mencakup sumber daya manusia, sosial, alam, fisik dan finansial. Aset penghidupan adalah penentu tingkat pendapatan dan ketahanan rumah tangga dalam menghadapi aneka risiko penghidupan, yang berarti juga kemungkinan terbebas dari kemiskinan secara berkelanjutan.

Perspektif aset livelihood sebagai basis untuk memenuhi kebutuhan dasar rumah tangga berpendapatan rendah dikenal sebagai pendekatan penghidupan berkelanjutan (SLA). SLA dipelopori oleh Departemen Pembangunan Internasional Kerajaan Inggris untuk digunakan dalam mengkaji dan merancang program pengentasan kemiskinan di negara-negara berkembang (Chambers \& Conway, 1992; Scoones, 1998; Carney, 2002). SLA kemudian diadopsi oleh berbagai lembaga pembangunan internasional terkemuka, seperti Swedish International Development Cooperation Agency (Krantz, 2001), CARE International (Frankenberger et al., 2000), dan Program Pembangunan PBB (UNDP, 2017). Selain dalam praksis pembangunan, SLA juga dipergunakan sebagai dasar dalam melakukan penelitian masyarakat berpendapatan rendah di negara-negara berkembang (Tao \& Wall, 2009; Julka \& Das, 2015; Serrat, 2017; Pukuh \& Widyasthika, 
2018; Su et al., 2018, Tarigan et al., 2019).

Kebaruan utama penelitian ini adalah yang pertama mengkaji pengaruh pemilikan aset TIK terhadap kemiskinan petani. Sepanjang pengetahuan penulis, hingga kini belum ada penelitian tentang pengaruh pemilikan peralatan TIK terhadap kemiskinan petani di Indonesia. Dari kajian literatur, ditemukan beberapa penelitian tentang pengaruh TIK terhadap kemiskinan di Indonesia secara total (Widiyastuti, 2015; Khoirunnisa \& Budiarti, 2019). Arifin (2011) meneliti pengaruh pemilikan telepon genggam terhadap pengeluaran rumah tangga per kapita di Indonesia. Ariansyah (2018) meneliti pengaruh internet terhadap pendapatan per kapita rumah tangga pedesaan di Indonesia. Tidak terdapat penelitian terdahulu yang secara khusus meneliti pengaruh TIK terhadap kemiskinan petani di Indonesia.

\section{Metodologi}

Model analisis disusun mengacu pada SLA yang menyatakan bahwa livelihood ditentukan oleh penguasaan aset livelihood yang mencakup sumber daya manusia (M), sosial budaya (S), alam (A), finansial (F), dan fisik (P), serta konteks sosial, ekonomi, dan lingkungan $(\mathrm{K})$. Model umum kecenderungan rumah tangga bersatus miskin diukur dengan logit.

$$
\begin{aligned}
& \text { Logit }=\ln (P /(1-P))=a_{0}+\sum a_{i} A_{i} \\
& P /(1-P)=O D D=\exp \left(a_{0}+\sum a_{i} A_{i}\right)
\end{aligned}
$$

$\mathrm{P}=$ Peluang bersatus miskin, $\mathrm{A}_{i}=$ Aset penghidupan ke $\mathrm{i}$

Odds menunjukkan kemungkinan (kecenderungan) terjadinya status miskin. Odds Ratio (OR) adalah rasio Odds pada dua status (nilai) prediktor. OR adalah ukuran asosiasi status kemiskinan dengan status (nilai) prediktor. Untuk penyederhanaan dalam menghitung $O R$, dimisalkan prediktor adalah peubah tunggal $X$ dengan koefisien logit c:

$$
P /(1-P)=O d d=e^{c X}
$$

Jika $X$ adalah peubah diskrit biner (bernilai 1,0) maka $O R$ adalah bilangan konstan, $O R=e^{c}$. Tetapi jika $X$ adalah peubah yang bernilai kontinu maka $e^{c}$ adalah dampak marjinal peningkatan satu unit peubah $X$ terhadap Odd. Nilai $O R$ bisa antara 0 hingga tidak terhingga. $\mathrm{OR}=1$ berarti prediktor tidak berpengaruh atau netral. $O R>1$ berarti prediktor berasosiasi dengan peningkatan kemiskinan. $O R<1$ berarti berasosiasi dengan penurunan kemiskinan. Namun demikian, interpretasi $<1$ tak mudah dinarasikan sehingga biasanya cara menafsirkannya dilakukan terbalik dengan memakai Inverse OR (IOR). Chen et al. (2010) menyatakan bahwa $\mathrm{OR}=(1,00-1,68)$ adalah trivial (tidak penting), $\mathrm{OR}=(1,68-3,47)$ adalah kecil, $\mathrm{OR}=(3,47-6.7)$ adalah sedang, dan $O R \geq 6,71$ adalah besar. Untuk 
tujuan praktik perencanaan, Olivier et al. (2017) menyarankan kriteria yang lebih moderat, yakni $\mathrm{OR}=(1,00-1,22)$ adalah trivial, $\mathrm{OR}=(1,22-1,86)$ adalah kecil, $\mathrm{OR}=(1,86-3.00)$ adalah sedang, dan $O R \geq 3,00$ adalah besar.

Model logit menunjukkan kemungkinan $(O d d)$ dan asosiasi $(O R)$ peubah bebas (miskin) dengan prediktor (aset livelihood), namun tidak menjelaskan bagaimana korelasi tersebut terjadi. Media transmisi pengaruh aset terhadap status kemiskinan ialah daya beli per kapita. Karena itu, hasil analisis odd dan $O R$ berdasarkan fungsi probabilitas logit diuji relasinya dengan analisis pengeluaran per kapita. Aset livelihood mempngaruhi daya beli (pengeluaran per kapita) yang selanjutnya mempengaruhi status kemiskinan. Fungsi pengeluaran diduga dengan regresi linier:

$$
\operatorname{Expc}=a_{0}+\sum a_{i} A_{i}
$$

Expc $=$ Pengeluaran per kapita

Suatu aset livelihood disimpulkan berpengaruh terhadap status kemiskinan jika berpengaruh nyata terhadap status kesejahteraan berdasarkan analisis daya beli dan berasosiasi nyata (tidak trivial) berdasarkan analisis OR. Analisis OR adalah uji syarat keharusan sedangkan analisis daya beli adalah uji syarat kecukupan.

Spesifikasi model empiris disesuaikan dengan ketersediaan data. Data yang dipergunakan diperoleh dari Survei Sosial Ekonomi Nasional (Susenas) tahun 2017 yang dipublikasi oleh Badan Pusat Statistik. Responden adalah Rumah Tangga Pertanian di Pedesaan (RTPD) yang terdiri dari Rumah Tangga Usaha Pertanian (RTUP) dan Rumah Tangga Buruh Tani (RTBT). Pendugaan regresi dilakukan dengan perangkat lunak SAS, PROC LOGISTICS untuk menduga model logit dan PROC REG opsi stepwise backward untuk menduga fungsi pengeluaran.

\section{Hasil dan Pembahasan}

Hasil estimasi menunjukkan bahwa prediksi model logit cukup baik dalam menjelaskan data (Tabel 1). Model dinilai valid sebagaimana ditunjukkan oleh statistik Hosmer and Lemeshow $X^{2}=339$ (Prob< 0.0001). Asosiasi probabilitas prediksi dan respon teramati menunjukkan Concordant $=79.4 \%$, discordant $=20,0 \%$, dan tied $=0,6 \%$, Somers' $\mathrm{D}=0.594$, Gamma $=0.597$, Tau-a $=0.090$, dan $\mathrm{C}=0,797$ yang menunjukkan model hasil estimasi berada pada titik batas kategori baik dan hampir sangat baik. Statistik $X^{2}$ Likelihood Ratio, Score, dan Wald konsisten menunjukkan tidak ada peubah bebas yang nyata ditolak pada signifikansi kurang dari 0,0001. Kecuali jumlah anggota RT, seluruh koefisien prediktor bertanda negatif sehingga $O R<1$, dan oleh karena itu pembahasan akan dilakukan berdasarkan IOR (Inverse OR).

Dalam penelitian ini, dianalisis empat penciri aset sumber daya manusia rumah tangga (RT), yakni jenis kelamin (JKKK), umur (UMKK), tingkat pendidikan kepala keluarga (TPKK) dan jumlah anggota rumah tangga (JART). Analisis menunjukkan IOR=1.16 untuk JKKK, IOR=1.00 untuk UMKK, IOR=1.04 untuk 
TPKK, dan OR=1.921 JART. Berdasarkan kriteria besaran OR Olivier et al. (2017), dapat disimpulkan bahwa pengaruh penciri kepala keluarga (JKKK, UMKK, TPKK) tergolong trivial, sedangkan pengaruh jumlah anggota keluarga tergolong sedang. Ini berarti, seluruh penciri kepala keluarga (KK) yang dikaji berpengaruh netral terhadap status kemiskinan RTPD. Jumlah anggota rumah tangga adalah satu-satunya penciri sumber daya manusia yang berpengaruh nyata terhadap status kemiskinan RTPD. Dengan mengasumsikan bahwa prediktor JART adalah peubah kontinu dalam unit jiwa, sehingga OR menunjukkan peningkatan Odds untuk setiap peningkatan satu jiwa JART. Odds RTPD jatuh miskin dapat meningkat menjadi $92 \%$ untuk setiap pertambahan satu orang anggota rumah tangga.

Temuan bahwa jumlah anggota rumah tangga berpengaruh positif terhadap kemiskinan rumah tangga adalah sejalan dengan hasil penelitian Darsono \& Donkwa (2016) pada rumah tangga pedesaan di Kalimantan Barat, serta penelitian Pukuh \& Widyasthika (2018) berdasarkan data Susenas 2016. Namun demikian, temuan tersebut bertentangan dengan pandangan tradisi bahwa banyak anak banyak rejeki. Secara rasional pandangan tradisi ini adalah benar jika pertambahan jumlah anggota rumah tangga meningkatkan jumlah angkatan kerja dengan pendapatan memadai (di atas garis kemiskinan). Sebaliknya, jika pertambahan jumlah anggota rumah tangga menambah ketergantungan angkatan kerja, atau tidak menambah pendapatan yang memadai, maka hal itu akan menambah beban kebutuhan hidup keluarga sehingga menyebabkan keluarga jatuh miskin. Temuan penelitian menunjukkan bahwa upaya penurunan jumlah anggota rumah tangga melalui program Keluarga Berencana dapat mengurangi tingkat kemiskinan rumah tangga pertanian. Hasil estimasi koefisien pemilik lahan bertanda negatif dan nyata secara statistik dengan $\mathrm{OR}=0,71(\mathrm{IOR}=1,40)$ yang berarti kemungkinan RTPD pemilik lahan terbebas dari kemiskinan adalah $40 \%$ lebih tinggi daripada yang tidak memiliki lahan. Asosiasi kepemilikan lahan dengan tingkat kemiskinan adalah signifikan walau tergolong kecil menurut kritera Olivier et al. (2017). Temuan ini sangat logis karena lahan dapat dipakai berusaha (termasuk pertanian) sendiri atau disewakan kepada pihak lain.

Akses kredit dan penabung adalah variabel aset finansial yang datanya tersedia untuk penelitian ini. Hasil estimasi regresi logistik menunjukkan bahwa koefisien kedua variabel bertanda negatif dan nyata secara statistik dengan $\mathrm{OR}=0,73$ $(\mathrm{IOR}=1,37)$ untuk akses kredit dan $\mathrm{OR}=0,40$ (inverse $\mathrm{IOR}=2,52)$ untuk penabung. Besaran OR prediktor penabung tergolong kecil, sedangkan OR prediktor akses kredit tergolong sedang (namun tertinggi dari seluruh prediktor) menurut kriteria Olivier et al. (2017). Hal ini menunjukkan bahwa akses terhadap lembaga keuangan dapat mengurangi risiko terjerumus dalam kemiskinan. RTPD yang mendapat akses kredit terbebas dari kemiskinan dengan odds sebesar 1,37 kali dari yang tidak memiliki akses kredit, sedangkan RTPD penabung terbebas dari kemiskinan dengan odds sebesar 2,52 kali dari non-penabung. Temuan ini sangat logis dan selanjutnya akan ditelusur apakah kedua prediktor berhubungan kasual atau berasosiasi dengan kemiskinan RTPD. 
Tabel 1: Hasil Estimasi Model Logistik Probabilitas Jatuh Miskin RTPD

\begin{tabular}{|c|c|c|c|c|c|c|}
\hline Peubah & Unit & Koefisien & $\operatorname{Pr}>X^{2}$ & Wald $X^{2}$ & OR & Inverse OR \\
\hline Peubah tak bebas: Miskin & $\mathrm{Ya}=1$ & & & & & \\
\hline Intersep & & -1.796 & $<.0001$ & 1610 & & \\
\hline KK wanita & $Y a=1$ & -0.1453 & $<.0001$ & 47,39 & 0.865 & 1.156 \\
\hline Umur KK & Tahun & -0.0046 & $<.0001$ & 48,56 & 0.995 & 1.005 \\
\hline Lama Pendidikan KK & Tahun & -0.0412 & $<.0001$ & 495 & 0.96 & 1.042 \\
\hline Jumlah anggota RT & Orang & 0.6529 & $<.0001$ & 7,439 & 1.921 & 0.521 \\
\hline Pemilik lahan & $\mathrm{Ya}=1$ & -0.3397 & $<.0001$ & 460 & 0.712 & 1.404 \\
\hline Akses kredit & $\mathrm{Ya}=1$ & -0.3124 & $<.0001$ & 245 & 0.732 & 1.366 \\
\hline Penabung & $\mathrm{Ya}=1$ & -0.9229 & $<.0001$ & 2.59 & 0.397 & 2.519 \\
\hline Akses listrik & $\mathrm{Ya}=1$ & -0.3833 & $<.0001$ & 366 & 0.682 & 1.466 \\
\hline Pemilik telepon & $\mathrm{Ya}=1$ & -0.6261 & $<.0001$ & 1.447 & 0.535 & 1.869 \\
\hline Pemilik komputer & $\mathrm{Ya}=1$ & -0.6565 & $<.0001$ & 122 & 0.519 & 1.927 \\
\hline Akses internet & $\mathrm{Ya}=1$ & -0.8277 & $<.0001$ & 394 & 0.437 & 2.288 \\
\hline Internet produktif & $\mathrm{Ya}=1$ & -0.4049 & $<.0001$ & 806 & 0.667 & 1.499 \\
\hline $\mathrm{X}^{2}$ Likelihood Ratio & & 27,287 & $<.0001$ & \multirow{3}{*}{\multicolumn{3}{|c|}{$\begin{array}{l}\text { Assosiasi prediksi probabilitas: } \\
\text { Max rescaled } \mathrm{R}^{2}=0,2019, \\
\text { Lemeshow } \mathrm{X}^{2}=339(\text { Prob }<0,001) \\
\text { Concordant }=79.4 \% \text {, } \\
\text { Somers' } \mathrm{D}=0.594 ; \text { Gamma }=0.597 ; \\
\text { Tau- } \mathrm{a}=0.090 ; \mathrm{c}=0.797\end{array}$}} \\
\hline $\mathrm{X}^{2}$ Score & & 27,944 & $<.0001$ & & & \\
\hline $\mathrm{X}^{2}$ Wald & & 20.871 & $<.0001$ & & & \\
\hline
\end{tabular}

Keterangan: KK = Kepala Keluarga. RT = Rumah Tangga.

Hasil estimasi koefisien untuk variabel akses listrik bertanda negatif dan nyata secara statistik dengan $\mathrm{OR}=0,68(\mathrm{IOR}=1,47)$. Artinya, rumah tangga pertanian yang memiliki akses listrik kemungkinan tidak miskin dengan odds sebesar 1,47 kali dari yang tidak memiliki akses listrik. OR prediktor akses listrik adalah nyata walau tergolong kecil menurut kriteria Olivier et al. (2017). Pertanyaan kemudian, yakni apakah akses listrik berfungsi sebagai indikator (relasi asosiatif) atau determinan kemiskinan (relasi kausal). Relasi asosiatif terjadi jika akses listrik merefleksikan status kekayaan, sedangkan relasi kausal dapat terjadi jika akses listrik bermanfaat sebagai sarana produktif. Isu ini selanjutnya akan dikaji melalui analisis pengeluaran.

Telepon (utamanya telepon genggam), komputer dan internet adalah peralatan informasi dan telekomunikasi modern (digital) yang baru masuk ke pedesaan dalam beberapa tahun terakhir. Hasil estimasi regresi logistik menunjukkan bahwa pemilikan telepon, komputer, dan akses internet berpengaruh negatif dan nyata terhadap risiko rumah tangga tani dengan IOR=2,29 untuk akses internet, IOR $=1,93$ untuk kepemilikan komputer, $\mathrm{IOR}=1,87$ untuk pemilikan telepon, dan $\mathrm{OR}=\mathrm{IOR}=1,50)$ untuk pengguna internet produktif. Berdasarkan kriteria Olivier et al. (2017), besaran OR termasuk kategori sedang untuk prediktor akses internet, pemilikan komputer, dan pemilikan telepon serta kecil untuk prediktor pengguna internet produktif.

Estimasi fungsi pengeluaran dengan teknik backward stepwise regression mengeluarkan prediktor yang tidak nyata pada taraf 5\%, yakni umur KK untuk RTBT, serta akses listrik dan Pemanfaatan internet produktif untuk seluruh RTPD (Tabel 
2). Tanda dari seluruh koefisien dugaan untuk seluruh prediktor yang nyata secara statistik adalah sesuai dengan perkiraan teoretis dan konsisten dengan hasil analisis fungsi logit sebagaimana telah dibahas sebelumnya. Rekapitulasi analisis fungsi logit dan pengeluaran dirangkum dalam Tabel 3. Prediktor yang dipandang efektif untuk menurunkan risiko RTPD terjerumus dalam kemiskinan ialah yang memiliki dampak nyata (kecil hingga besar), tidak trivial atau tidak nyata, berdasarkan analisis logit, dan memiliki relasi kausal, bukan asosiatif, berdasarkan analisis daya beli.

Tabel 2: Hasil Estimasi Fungsi Pengeluaran per Kapita Menurut Pekerjaan Utama KK

\begin{tabular}{|c|c|c|c|c|c|}
\hline \multirow{2}{*}{ Prediktor } & \multirow{2}{*}{ Unit } & \multicolumn{2}{|c|}{ RTUP } & \multicolumn{2}{|c|}{ RTBT } \\
\hline & & Koefisien & $\operatorname{Pr}>t$ & & $\operatorname{Pr}>t$ \\
\hline Intersep & & 703.823 & $<.0001$ & 958.635 & $<.0001$ \\
\hline KK wanita & $Y a=1$ & 76.853 & $<.0001$ & 152.494 & $<.0001$ \\
\hline Umur KK & Tahun & 4.025 & $<.0001$ & \multicolumn{2}{|c|}{ Tidak nyata } \\
\hline Lama pendidikan KK & Tahun & 10.589 & $<.0001$ & 14.057 & $<.0001$ \\
\hline Jumlah anggota RT & Orang & -97.983 & $<.0001$ & -111.664 & $<.0001$ \\
\hline Pemilik lahan & $\mathrm{Ya}=1$ & 41.686 & $<.0001$ & 69.855 & $<.0001$ \\
\hline Akses kredit & $\mathrm{Ya}=1$ & 97.41 & $<.0001$ & 104.166 & $<.0001$ \\
\hline Penabung & $\mathrm{Ya}=1$ & \multicolumn{2}{|c|}{ Tidak nyata } & \multicolumn{2}{|c|}{ Tidak nyata } \\
\hline Akses listrik & $\mathrm{Ya}=1$ & \multicolumn{2}{|c|}{ Tidak nyata } & \multicolumn{2}{|c|}{ Tidak nyata } \\
\hline Pemilik telepon & $\mathrm{Ya}=1$ & 146.769 & $<.0001$ & 179.998 & $<.0001$ \\
\hline Pemilik komputer & $\mathrm{Ya}=1$ & 297.035 & $<.0001$ & 489.639 & $<.0001$ \\
\hline Akses internet & $\mathrm{Ya}=1$ & 296.493 & $<.0001$ & 288.01 & 0.0029 \\
\hline Internet produktif & $\mathrm{Ya}=1$ & \multicolumn{2}{|c|}{ Tidak nyata } & \multicolumn{2}{|c|}{ Tidak nyata } \\
\hline Adj $R-S q$ & & \multicolumn{2}{|l|}{0,0979} & \multicolumn{2}{|l|}{0,1045} \\
\hline
\end{tabular}

Satu-satunya penciri sumber daya manusia RTPD yang berpengaruh nyata walau dengan skala kecil dan dengan relasi kasual ialah prediktor jumlah anggota keluarga. Seluruh prediktor penciri sumber daya manusia RTPD lainnya berdampak trivial terhadap status kesejahteraan. Pemilik lahan dan akses kredit juga berdampak trivial dengan relasi kausal. Sekali pun memiliki relasi kauasal, yang berati berkontribusi untuk meningkatkan daya beli RTPD, seluruh prediktor trivial tidak efektif untuk menurunkan risiko RTPD terjerumus dalam kemiskinan sehingga tidak layak dijadikan sebagai pilihan instrumen kebijakan pengentasan kemiskinan.

Prediktor penabung, akses listrik, dan internet produktif juga dipandang tidak layak dijadikan sebagai instrumen kebijakan karena walaupun berdampak nyata (kategori sedang atau kecil), namun relasinya asosiatif yang berarti belum terbukti berpengaruh nyata terhadap daya beli per kapita RTPD. Kasus ini mungkin tidak segera dapat dipahami dengan akal sehat karena penggunaan ketiga prediktor tersebut tidak berpengaruh terhadap peningkatan daya beli. Menabung dapat dipandang menyimpan kelebihan daya beli yang belum tentu meningkatkan daya beli sehingga berasosiasi dengan status kesejahteraan, namun tidak berkontribusi untuk peningkatan daya beli. Begitu juga dengan akses listrik yang bisa merefleksikan status kesejahteraan (berasosiasi dengan kemiskinan), namun belum tentu berdampak pada peningkatan daya beli RTPD. Terkait dengan inter- 
net produktif, kemungkinan jumlah pengguna internet "produktif" masih sedikit sehubungan dengan masih rendahnya akses maupun tingkat pengetahuan RTPD dalam pemanfaatan internet secara produktif.

Berdasarkan kriteria berdampak nyata non-trivial dan kausal, maka prediktor yang dapat dijadikan instrumen kebijakan ialah sebagai berikut: (1) Prioritas pertama, prediktor berdampak sedang, yaitu: akses internet, pemilikan komputer, dan pemilikan telepon; (2) Prioritas kedua, prediktor berdampak kecil, yaitu: akses kredit dan pemilikan lahan; (3) Prioritas ketiga, relevan untuk jangka menengah panjang, yaitu jumlah anggota rumah tangga dan pemilikan lahan.

\section{Tabel 3: Rekapitulasi Analisis Kemungkinan, Relasi dan Simpulan Prediktor Kemiskinan}

\begin{tabular}{lccc}
\hline \hline \multirow{2}{*}{ Prediktor } & \multirow{2}{*}{ Besaran OR } & \multicolumn{2}{c}{ Relasi } \\
\cline { 3 - 4 } & & RTUP & RTBT \\
\hline KK wanita & Trivial & Kausal & Kausal \\
Umur KK & Trivial & Kausal & Asosiatif \\
Pendidikan KK & Trivial & Kausal & Kausal \\
Jumlah anggota RT & Sedang & Kausal & Kausal \\
Pemilikan lahan & Kecil & Kausal & Kausal \\
Akses kredit & Kecil & Kausal & Kausal \\
Penabung & Sedang & Asosiatif & Asosiatif \\
Akses listrik & Kecil & Asosiatif & Asosiatif \\
Pemilik telepon & Sedang & Kausal & Kausal \\
Pemilik komputer & Sedang & Kausal & Kausal \\
Akses internet & Sedang & Kausal & Kausal \\
Internet produktif & Kecil & Asosiatif & Asosiatif \\
\hline Sumber: Tabel 1 dan 2 & & &
\end{tabular}

Menarik kiranya diperhatikan bahwa ketiga prioritas pertama tersebut ( $a k$ ses internet, pemilikan komputer, dan pemilikan telepon) termasuk satu kategori teknologi, yakni teknologi informasi dan telekomunikasi (TIK [Information and Communication Technology/ICT]) atau lebih dikenal dengan sebutan Teknologi Digital. (Inverse) OR ketiga prediktor ini adalah tiga terbesar dari seluruh penciri kepemilika aset yang diuji dan tergolong sedang menurut kriteria Olivier et al. (2017). Selain itu, ketiga prediktor terbukti berpengaruh nyata terhadap daya beli per kapita yang mengindikasikan bahwa TIK berkontribusi dalam penghidupan RTPD. Barangkali tidak berlebihan untuk mengatakan bahwa korelasi akses terhadap TIK digital adalah determinan utama kemungkinan RTPD keluar dari kemiskinan. Namun demikian, perlu menjadi catatan bahwa penggunaan TIK digital di pedesaan Indonesia masih relatif baru. Peralatan TIK digital tergolong mahal dan pemanfaatannya pun tidak mudah bagi RTPD berpendapatan rendah. Oleh karena itu, program digitalisasi pertanian dan pedesaan inklusif sebaiknya dijadikan sebagai program prioritas nasional, sehingga dapat menjangkau petani berpendapatan rendah.

Walau tidak sebesar akses TIK, akses kredit dan pemilikan lahan berpengaruh nyata terhadap kemungkinan RTPD terbebas dari risiko terjerumus dalam kemiskinan dengan besaran kecil menurut klasifikasi Olivier et al. (2017). Akses kredit 
dan pemilikan lahan berkontribusi langsung dalam peningkatan daya beli RTPD. Hal ini sangat jelas karena kredit dari lembaga keuangan dapat dipergunakan sebagai modal berusaha untuk meningkatkan pendapatan dan/atau alat berbelanja, sementara lahan adalah basis usaha pertanian. Akses kredit dapat ditingkatkan melalui pengembangan kelembagaan pembiayaan khusus bagi petani, termasuk yang berbasis digital atau pembiayaan elektronik (e-Finance). Dengan demikian, digitalisi pertanian termasuk pengembangan $e$-Finance, merupakan strategi yang tepat untuk mengentaskan kemiskinan pada petani. Penurunan jumlah anggota rumah tangga melalui program Keluarga Berencana adalah instrumen kebijakan jangka menengah-panjang karena membutuhkan kesadaran dan keyakinan terkait reproduksi manusia. Dengan demikian, penurunan jumlah anggota rumah tangga dapat dipandang sebagai komplentaritas dari usulan Program Digitalisasi Pertanian dan Pedesaan.

\section{Kesimpulan}

Akses terhadap teknologi informasi dan komunikasi (TIK) digital yang mencakup akses internet, pemilikan komputer, dan pemilikan telepon adalah prediktor utama dan berhubungan kausal dengan kemiskinan rumah tangga pertanian di pedesaan. Pengaruh akses perkreditan dan akses lahan terhadap kemungkinan rumah tangga pertanian terbebas dari kemiskinan juga nyata dan berhubungan kausal, namun besarannya tergolong kecil. Aspek sumber daya manusia yang paling berpengaruh terhadap status kemungkinan rumah tangga pertanian ialah jumlah anggota rumah tangga yang berdampak sedang. Walaupun berhubungan kausal melalui daya beli, pengaruh karakteristik sumber daya manusia lainnya terhadap status kemiskinan rumah tangga pertanian adalah bersifat trivial (tidak berarti sehingga dapat diabaikan).

Berdasarkan temuan penelitian, maka disarankan agar program pengentasan kemiskinan pada rumah tangga pertanian dapat difokuskan pada tiga instrumen utama. Pertama, mendorong percepatan penyediaan infrastruktur, fasilitasi akses, serta dukungan pemanfaatan teknologi digital di pedesaan secara umum dan di pertanian secara khusus. Untuk itu, pemerintah perlu merancang dan melaksanakan program khusus digitalisasi pertanian inklusif (yang menjangkau petani gurem dan buruh tani). Kedua, meningkatkan akses kredit pembiayaan penghidupan untuk petani, termasuk melalui pengembangan e-Finance berbasis TIK, terpadu dengan program digitalisasi pertanian dan pedesaan. Ketiga, mendorong optimasi dan ekstensifikasi lahan pertanian. Instrumen ketiga ini pun sebaiknya diintegrasikan dengan program digitalisasi pertanian dan pedesaan. Sehubungan dengan itu, disarankan agar Pemerintah melaksanakan strategi transformasi pertanian dan pedesaan melalui Program Digitalisasi Inklusif untuk Percepatan Pembangunan Pertanian dan Pedesaan yang mengintegrasikan usaha pertanian dengan perekonomian desa, termasuk pembiayaan pertanian, serta optimasi dan ekstensifikasi lahan pertanian. Dalam jangka panjang, program tersebut perlu disertai dengan kampanye pengurangan jumlah anggota rumah 
tangga melalui Program Keluarga Berencana.

\section{Daftar Pustaka}

[1] Ariansyah, K. (2018). The importance of the internet on improving economic welfare: An empirical evidence from Indonesian rural household. In 2018 International Conference on ICT for Rural Development (IC-ICTRuDev) (pp. 118-123), 17-18 October 2018, Badung Regency, Indonesia. IEEE. doi: https://doi.org/10.1109/ICICTR.2018.8706868.

[2] Arifin, Z. (2011). The impact of mobile phones on household welfare in Indonesia: Evidence and implications (Master's thesis, University of Pittsburgh). http://d-scholarship.pitt. edu/10952/.

[3] Carney, D. (2002). Sustainable livelihoods approaches: Progress and possibilities for change. Department for International Development.

[4] Chambers, R., \& Conway, G. (1992). Sustainable rural livelihoods: practical concepts for the 21st century. IDS Discussion Paper No. 296. Institute of Development Studies. https://opendocs.ids.ac.uk/opendocs/handle/20.500.12413/775.

[5] Chen, H., Cohen, P., \& Chen, S. (2010). How big is a big odds ratio? Interpreting the magnitudes of odds ratios in epidemiological studies. Communications in StatistiCS-simulation and Computation ${ }^{\circledR}, 39(4)$, 860-864. doi: 10.1080/03610911003650383.

[6] Darsono, S. N. A. C., \& Donkwa, M. (2016). Factors analysis of household poverty in rural area of West Kalimantan, Indonesia. Advances in Management $\mathcal{E}$ Applied Economics, 6(6), 15-28.

[7] Frankenberger, T., Drinkwater, M., \& Maxwell, D. (2000). Operationalizing household livelihood security: A holistic approach for addressing poverty and vulnerability. CARE International. http://www.fao.org/3/x9371e/x9371e12.htm.

[8] Julka, P. \& Das, S. (2015). Female headed households and poverty: Analysis using household level data. Working Paper 133/2015. India: Madras School of Economics. https://www.mse.ac.in/wp-content/uploads/2016/09/Working-Paper-133.pdf.

[9] Kadir, K. \& Rizki, A. R. (2016). Economic growth and poverty reduction: The role of the agricultural sector in rural Indonesia. Proceedings ICAS VII Seventh International Conference on Agricultural Statistics, Rome 24-26 October 2016 (pp. 100-105).https: //www.istat.it/storage/icas2016/a03-kadir.pdf.

[10] Khoirunnisa \& Budiarti, W. (2019). Pengaruh teknologi informasi dan komunikasi terhadap tingkat kemiskinan di Indonesia tahun 2012-2017. Seminar Nasional Official Statistics 2019: Pengembangan Official Statistics dalam mendukung Implementasi SDG's, 2019(1), 759-768. doi: https://doi.org/10.34123/semnasoffstat.v2019i1.186.

[11] Krantz, L. (2001). The sustainable livelihood approach to poverty reduction: An introduction. Swedish International Development Cooperation Agency (SIDA). https://www.sida.se/contentassets/bd474c210163447c9a7963d77c64148a/ the-sustainable-livelihood-approach-to-poverty-reduction_2656.pdf.

[12] McArthur, J. W. (2015). Agriculture's role in ending poverty. In L. Chandy, H. Kato, H. Kharas (eds.), The last mile in ending extreme poverty, pp. 175-218. Brookings Institution Press.

[13] Olivier, J., May, W. L., \& Bell, M. L. (2017). Relative effect sizes for measures of risk. Communications in Statistics-Theory and Methods, 46(14), 6774-6781. doi: 10.1080/03610926.2015.1134575.

[14] Pukuh, N. \& Widyasthika, H. F. (2018). Women left behind? Findings from female 
headed household in Indonesia. Proceeding International Conference and Workshop on Gender "Women's Leadership and Democratisation in the 21st Century Asia", pp. 397-410, Jakarta, 27-28 April 2018.

[15] Scoones, I. (1998). Sustainable rural livelihoods: A framework for analysis. IDS Working Paper 72. Institute of Development Studies. https://opendocs.ids.ac.uk/ opendocs/handle/20.500.12413/3390.

[16] Serrat O. (2017). The sustainable livelihoods approach. In O. Serrat, Knowledge Solutions, pp 21-26. Springer, Singapore. doi: https:/ / doi.org/10.1007/978-981-10-0983$9 \cdot 5$.

[17] Simatupang, P., \& Dermoredjo, S. K. (2003). Produksi Domestik Bruto, harga dan kemiskinan: Hipotesis "trickle down" dikaji ulang. Ekonomi dan Keuangan Indonesia, 51(3), 291-324.

[18] Su, M., Sun, Y., Min, Q., \& Jiao, W. (2018). A community livelihood approach to agricultural heritage system conservation and tourism development: Xuanhua Grape Garden urban agricultural heritage site, Hebei Province of China. Sustainability, 10(2), 361. doi: $10.3390 /$ su10020361.

[19] Suryahadi, A., Hadiwidjaja, G., \& Sumarto, S. (2012). Economic growth and poverty reduction in Indonesia before and after the Asian financial crisis. Bulletin of Indonesian Economic Studies, 48(2), 209-227. doi: https://doi.org/10.1080/00074918.2012.694155.

[20] Susilastuti, D. (2018). Agricultural production and its implications on economic growth and poverty reduction. European Research Studies Journal, 21(1), 309-320. doi: $10.35808 / \mathrm{ersj} / 949$.

[21] Tao, T. C. H., \& Wall, G. (2009). A livelihood approach to sustainability. Asia Pacific Journal of Tourism Research, 14(2), 137-152. doi: https://doi.org/10.1080/10941660902847187.

[22] Tarigan, H., Simatupang, P., Wahyuni, S. \& Maulana, M. (2019). Strategi penanggulangan kemiskinan di pertanian dan perdesaan. Laporan Teknis. Pusat Sosial Ekonomi dan Kebijakan Pertanian, Bogor.

[23] [UNDP] United Nations Development Programme. (2017). Guidance Note: Application of the sustainable livelihood framework in development project. UNDP Regional Center for Latin America and Panama. https: //www.latinamerica.undp.org/content/rblac/en/home/library/poverty/ guidance-note--application-of-the-sustainable-livelihoods-framew.html.

[24] Widiyastuti, I. (2015). Analisis runtun waktu dalam pengujian pengaruh TIK terhadap penurunan laju kemiskinan di Indonesia. IPTEKKOM: Jurnal Ilmu Pengetahuan dan Teknologi Komunikasi, 17(1), 19-30. doi: http://dx.doi.org/10.33164/iptekkom.17.1.2015.19-30. 
this page intentionally left blank 